\title{
Absence of sibutramine effect on spontaneous anxiety in rats
}

\author{
Ausência de efeito da sibutramina na \\ ansiedade espontânea em ratos
}

Silvana S. Frassetto ${ }^{1,2}$, Isis O. Alves ${ }^{2}$, Marislane M. Santos ${ }^{3}$, Ana E. S. Schmidt ${ }^{3}$, Janaína J. Lopes ${ }^{2}$, Paulo A. Oliveira ${ }^{2}$, Anapaula S. Vinagre ${ }^{4}$, Patrícia Pereira ${ }^{2}$

\begin{abstract}
Introduction: Sibutramine has been described as a drug recommended for treatment of obesity, since it has the ability to inhibit the reuptake of serotonin and noradrenaline in the central nervous system, thereby increasing energy expenditure. Objective: Investigate the anxiogenic and anxiolytic effects of acute and chronic treatment with sibutramine in rats submitted to the task of the elevated plus-maze. Methods: Diazepam was used as a positive control for the anxiolytic effect, and the task of the elevated plus-maze showed sensitivity to detect the effect. In the chronic treatment, sibutramine was ingested for a period of two months. Results: The acute and chronic treatments at the studied dose, which is described to produce a maximum effect of anti-obesity in rats, did not interfere with anxiety. Conclusions: The acute and chronic administration of sibutramine is not related to anxiolytic or anxiogenic effects. Arq Bras Endocrinol Metab. 2010;54(4):375-80

\section{Keywords}

Anxiety; elevated plus-maze; obesity; sibutramine
\end{abstract}

\section{RESUMO}

Introdução: A sibutramina tem sido descrita como um fármaco recomendado para o tratamento da obesidade, uma vez que tem a capacidade de inibir a recaptação de serotonina e noradrenalina no sistema nervoso central, aumentando assim o gasto energético. Objetivo: Investigar os efeitos ansiogênico e ansiolítico dos tratamentos agudo e crônico com a sibutramina em ratos Wistar submetidos à tarefa do labirinto em cruz elevado. Métodos: 0 diazepam foi usado como controle positivo para o efeito ansiolítico, e a tarefa do labirinto em cruz elevado apresentou sensibilidade para detectar o efeito. No tratamento crônico, a sibutramina foi ingerida por um período de dois meses. Resultados: Os tratamentos agudo e crônico, na dose estudada, que é descrita para produzir um efeito de antiobesidade máxima em ratos, não interferem na ansiedade. Conclusões: As administrações aguda e crônica de sibutramina não estão relacionadas aos efeitos ansiolítico ou ansiogênico. Arq Bras Endocrinol Metab. 2010;54(4):375-80

Descritores

Ansiedade; labirinto em cruz elevado; obesidade; sibutramina

\section{INTRODUCTION}

Cerotonin (5-HT) and noradrenaline (NA) play an $\checkmark$ important role in the control of energy balance, and are involved in the symptomatology related to obesity, depression and anxiety. Thus, both neurotransmitter pathways have been given special attention as antiobesity and antidepressant agents (1).

Sibutramine (BTS54524; N-[1-[1(4-chloro phenyl) cyclobutyl]-3methyl $\mathrm{N}, \mathrm{N}$-dimethylamine hydrochloride monohydrate - Figure 1) has been described as a
${ }^{1}$ Curso de Ciências Biológicas, Universidade Luterana do Brazil (Ulbra), Canoas, RS, Brazil

${ }^{2}$ Curso de Farmácia e Biomedicina, Ulbra, Canoas, RS, Brazil ${ }^{3}$ Curso de Medicina, Ulbra, Canoas, RS, Brazil

${ }^{4}$ Departamento de Fisiologia, Universidade Federal do Rio Grande do Sul (UFRGS), Porto Alegre, RS, Brazil

\author{
Correspondence to: \\ Silvana S. Frassetto \\ Universidade Luterana do Brasil \\ Curso de Ciências Biológicas \\ Av. Farroupilha, 8001 \\ 92425-900 - Canoas, RS, Brazil \\ vana@terra.com.br
}

Received on Sept/3/2009

Accepted on Jan/20/2010 drug recommended for long-term treatment of obesity, since it has the ability to inhibit $5-\mathrm{HT}$ and NA reuptake, but without affinity to histaminic, muscarinic and alpha 1-adrenergic receptors (2-4). It has been affirmed that the in vivo effects of sibutramine are mediated by the inhibition of the reuptake of 5-HT and NA in the central nervous system, thus increasing the expenditure of energy (5-8). Furthermore, locomotion has been observed to be a major determinant of the sibutramine-induced increase in energy expenditure (9). Thus, although 
preliminary animal experimentation data have supported the antidepressant effect of sibutramine (10), less promising results have been obtained in clinical trials leading to its approval as an anti-obesity agent $(11,12)$.

On the other hand, nontriclyclic agents, such as selective serotonin (SSRI) and serotonin-noradrenaline (SNRI) reuptake inhibitors, have been preferred for use in the treatment of anxiety and depression, but have failed to achieve sustained weight loss in the treatment of obesity (1,13-15). Despite this, as with sibutramine, SSRIs and SNRIs have also increased locomotion $(16,17)$. Thus, it has been observed that reduction in anxiety through long-term treatment with serotonin reuptake inhibitors is probably related to the increase in locomotor activity, since diazepam as a rapidly-acting anxiolytic produces locomotor effects similar to those of these other drugs (17).

This study aims to investigate the acute and chronic effects of sibutramine on rats tested on the elevated plus-maze, and to describe the clinical status. We have demonstrated that the mechanisms modulated by $5-\mathrm{HT}_{2}$ receptors are involved in the increase of locomotion and in the lower increase in body weight of rats treated chronically with sibutramine (18). In the present paper we evaluated the acute and chronic effects of sibutramine on the elevated plus-maze task. Our hypothesis is that acute and chronic administration of sibutramine is not related to anxiolytic effects, despite the fact that locomotion-increasing behavior has been described as the most plausible hypothesis for the anxyolitic-like effects of serotonin reuptake inhibitors (17).

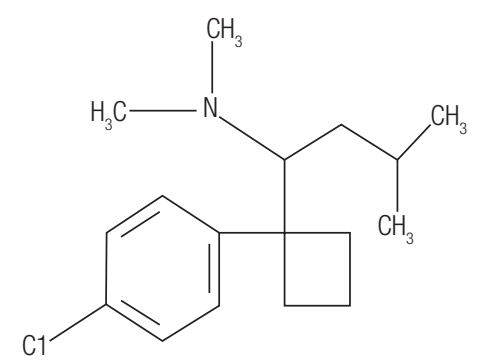

Figure 1. Structure of sibutramine.

\section{SUBJECTS AND METHODS}

\section{Subjects}

Male Wistar rats from our breeding colony weighing between $308.7 \pm 19.1 \mathrm{~g}$ (mean \pm S.E.M., $\mathrm{n}=70$ ) were used. They were housed individually in metabolic ca- ges, with controlled access to water and food, following a 12-h light/dark cycle (lights on at 7.00 AM) at a constant temperature of $23^{\circ} \mathrm{C}$. The normocaloric ration given to rats consisted of metabolizable energy $(\mathrm{ME})$ of about 2935 calories $\mathrm{ME} / \mathrm{kg}$ (carbohydrates = $1750 \mathrm{cal} . \mathrm{ME} / \mathrm{kg}$, fat $=485 \mathrm{cal} . \mathrm{ME} / \mathrm{kg}$, and protein $=700 \mathrm{cal} . \mathrm{ME} / \mathrm{kg}$ ). All experimental procedures were carried out in accordance with the guidelines recommended by the Brazilian Society for Neuroscience and Behavior (SBNeC) for animal care, and by National Institute of Health standards. The experimental protocol was approved by the Ethical Committee of the Lutheran University of Brazil.

\section{Drugs and treatment procedure}

In the acute treatment, sibutramine $\left(\right.$ Medley $\left.^{\circledR}\right)$ or diazepam $\left(\right.$ Sigma $\left.^{\circledR}\right)$ was dissolved in a saline solution. The rats received saline, diazepam $(1 \mathrm{mg} / \mathrm{kg})(19)$ or sibutramine $(10 \mathrm{mg} / \mathrm{kg})(20)$ intraperitoneally in a volume of $1 \mathrm{~mL} / \mathrm{kg}$. Diazepam was used as a positive control for the anxiolytic effect. The animals were separately subjected to the task thirty minutes after injection. In the chronic treatment sibutramine was administered to the rats daily over a period of two months $(4,18)$. During the experimental period the rats were kept in individual metabolic cages and given $40 \mathrm{~g}$ of food per day, plus $50 \mathrm{~mL}$ of liquid, in accordance with the following groups: 1) control: rats which received water; and 2) sibutramine: rats which received $14 \mathrm{mg} / \mathrm{kg} /$ day of sibutramine dissolved in water (21).

The final body weight of control rats and those who received sibutramine was $346.8 \pm 10.9 \mathrm{~g}$ and $301.2 \pm 8.3 \mathrm{~g}($ mean \pm S.E.M $)$, respectively. There were no differences between groups regarding the levels of plasma glucose and triglycerides after treatment. Glucose levels in control rats and those who received sibutramine were $134.8 \pm 6.8$ and $122.4 \pm$ $8.5 \mathrm{mg} / \mathrm{dL}$ (mean \pm S.E.M.), respectively. Plasma triglycerides in both groups were $44.0 \pm 3.7$ and 43.2 $\pm 5.7 \mathrm{mg} / \mathrm{dL}$ (mean \pm S.E.M.), respectively. The fluid intake was measured daily, and the average consumption was $37.2 \pm 4.2 \mathrm{~mL} /$ day $($ mean \pm S.E.M.). Thus, the sibutramine group ingested a concentration of $10.4 \pm$ $1.1 \mathrm{mg} / \mathrm{kg} /$ day (mean \pm S.E.M.) of the drug. The final concentration used has been described to produce maximal antiobesity effect, increasing satiety in rats (4). Furthermore, the selected dose reflected the usual dose pointed out in literature for experiments with rats $(22,23)$. 


\section{Elevated plus-maze task}

The elevated plus-maze task used in animal models of anxiety is described in detail elsewhere (24). Briefly, the apparatus consisted of two open arms $(50 \mathrm{~cm} \times 10 \mathrm{~cm})$ and two enclosed arms $(50 \mathrm{~cm} \times 10 \mathrm{~cm} \times 40 \mathrm{~cm})$, arranged in such a way that the two arms of each type were opposite to each other and to a platform $(10 \mathrm{~cm} \mathrm{x}$ $10 \mathrm{~cm}$ ). The height of the maze was $50 \mathrm{~cm}$, and the tests were conducted under dim red light. After the acute and chronic experiments, the animals were placed individually on the central platform of the plus-maze. During a 5 -minute test period, the following measurements were recorded by two observers: the number of entries and the time spent in the open and enclosed arms. Results are expressed as percentage of entries in the open and enclosed arms (\%Entries/Total) and percentage of time spent in these arms (\%Time spent/Total).

\section{Statistical analysis}

In the acute treatment, the comparison of elevated plusmaze data was examined through one-way ANOVA followed by Duncan's test. In the chronic treatment, data were analyzed by the Student $t$-test. The results were expressed as mean \pm S.E.M. In the comparison, $\mathrm{p}<0.05$ was considered as indicating statistical significance. Statistical tests were performed using the SPSS for Windows program.

\section{RESULTS}

The elevated plus-maze task of the rats given saline, diazepam and sibutramine in the acute treatment is shown in figure 2 . Sibutramine $(10 \mathrm{mg} / \mathrm{kg})$ did not alter the percentage of entries in the open and enclosed arms (Figure 2A; $\mathrm{p}=0.19$ ) and the percentage of time spent in these arms (Figure $2 \mathrm{~B} ; \mathrm{p}=0.13$ ) compared to saline group. Another concentration $(20 \mathrm{mg} / \mathrm{kg}) \mathrm{did}$ not show any effect on this task (results not shown). On the other hand, diazepam significantly increased the percentage of entries (Figure $2 \mathrm{~A}$ ) and time spent (Figure $2 \mathrm{~B})$ in the open arms $(\mathrm{p}<0.05)$ compared to the saline group. The behavior of rats who received water and those who received chronic treatment with sibutramine is shown in figure 3 . There were no significant differences between the groups regarding the percentage of entries (Figure 3A; $\mathrm{p}=0.11$ ) and time spent (Figure $3 \mathrm{~B} ; \mathrm{p}=0.09$ ) in the open and enclosed arms, suggesting that chronic treatment with sibutramine did not induce anxiolytic or anxiogenic effects.

\section{DISCUSSION}

The results of the elevated plus-maze task showed that acute and chronic treatments with sibutramine are not associated with the expression of anxiety-related behaviors (Figure 3 ). In the acute treatment, the percentage of entries and time spent in the enclosed arms were longer in the sibutramine group than in the saline group but the difference was not significant (Figures $2 \mathrm{~A}$ and $2 \mathrm{~B}$ ). Elevated plus-maze is a task which reliably detects the anxiolytic effect of clinically relevant benzodiazepine drugs (25), such as diazepam that display an anxiolytic-like behavioral profile with the percentage of entries and time spent in the open arms being increased (Figures 2A and 2B). On the other hand, drugs that elicit a decrease of the entries and time spent in the open arms are considered as anxiogenic (24). The results with diazepam validated the sensitivity of this model in our laboratory. Moreover, the elevated plus-maze has detected the anxiolytic effect of chronic milnacipran, a serotonin-noradrenaline reuptake inhibitor (SNRI) antidepressant (26), and the anxiogenic effect of acute fluoxetine and paroxetine (27). These findings favor the position that elevated plus-maze conventional measurements are sufficient and reliable for detecting anxiolytic or anxiogenic-like effects of antidepressant drugs.

Clinical evidence demonstrates that chronic treatment with drugs which inhibit 5-HT and NA reuptake is effective in treating anxiety-related diseases $(26,28)$. As regards the pharmacological profile of sibutramine, it was developed as an antidepressant drug (22), but with less promising results in clinical trials, leading to its approval as an anti-obesity agent $(11,12)$. The antiobesity effect of sibutramine is described as a consequence of a dual mechanism: a reduction of energy intake by increasing satiety, and an increase in energy expenditure (12). In relation to the increase in energy expenditure, this may be due to an increase of thermogenesis and locomotion, in cases where both 5-HT and NA systems are important regulators (9). Thus, we have demonstrated by means of an open-field task that mechanisms modulated by $5-\mathrm{HT}_{2}$ receptors are involved in the increase of locomotion in rats treated chronically with sibutramine (18).

Serotoninergic mechanisms of antidepressant agents, such as SSRIs (citalopran, fluoxetine, paroxetine, fluvoxamine) and SNRIs (venlafaxine, duloxetine), also play an important role in the increase of locomotor behavior $(16,17)$. Interestingly, a reduction in anxiety as a result 

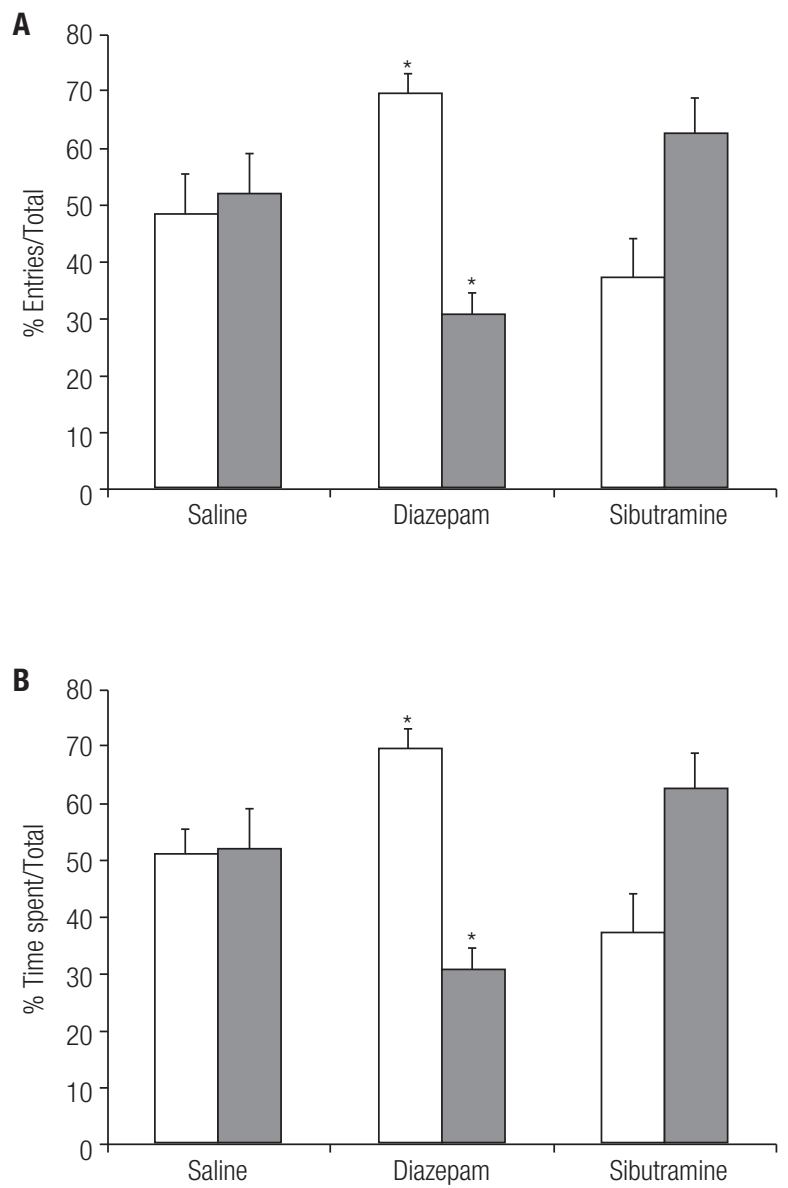

Figure 2. Effect of acute treatment with sibutramine or diazepam on percentage of entries $(\mathbf{A})$ and time spent $(\mathbf{B})$ in the open and enclosed arms. The values are shown as mean \pm S.E.M. ( $n=11-12$ animals per group). White columns: open arms. Gray columns: enclosed arms. ${ }^{*} p<0.05$ compared to saline.

of the chronic use of these drugs is observed as being related to the increase of locomotor activity under the conditions of a new environment, as is the case with diazepam as an anxiolytic agent (17). Furthermore, it has been observed that this response to SSRIs and SNRIs in motor behavior differentiates them from other classes of antidepressant agents which reduce anxiety but fail to increase locomotor activity, such as tricyclics (imipramine, amitriptyline) and the mixed SSRI/5- $\mathrm{HT}_{2}$ antagonists, nefazodone and trazodone (16).

Discussing the acute and chronic results, administration of established antidepressants in animals has been reported to produce anxiolytic- $(26,29)$ or anxiogeniclike $(27,30)$ effects in some studies and no specific effect in others $(27,31)$. Pharmacologic manipulations of the serotoninergic system in animal models indicate that different mechanisms, presumably due to 5-HT
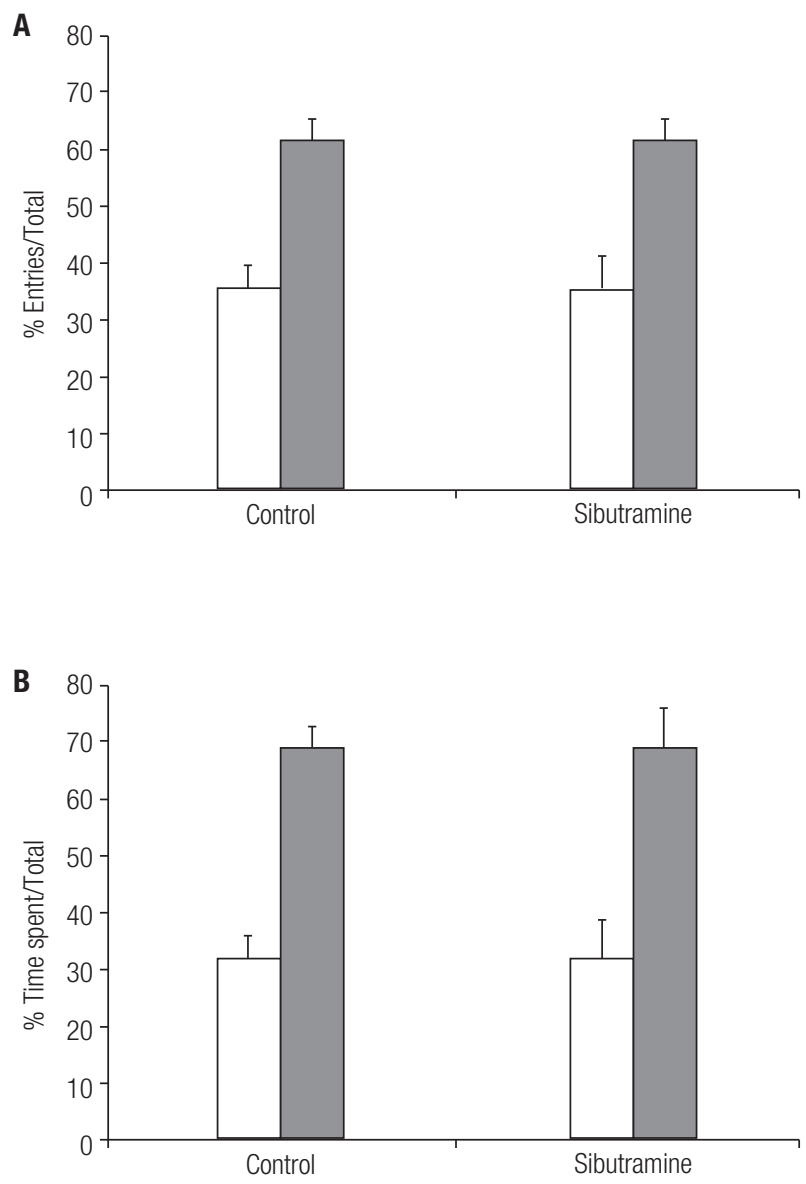

Figure 3. Effect of chronic treatment with sibutramine on percentage of entries (A) and time spent (B) in the open an enclosed arms. The values are shown as mean \pm S.E.M. ( $n=17-19$ animals per group). White columns: open arms. Gray columns: enclosed arms.

receptor specificities (32), are involved in the expression of anxiety-related behaviors $(33,34)$. It has been reported that the initial effect of acute administration of serotonergic compounds is increased anxiety (35). In addition, the interaction between 5-HT and NA may play an important role in the etiology of anxiety disorder (36). Consequently, it has been described that medications (SNRIs) modulating 5-HT and NA system can be an effective treatment of this disorder, such as milnacipran, venlafaxine and duloxetine (37).

In this study, we have hypothesized that the effect of inhibiting serotonin-noradrenaline reuptake by sibutramine could be effective in the long-term treatment of anxiety, but we have concluded that the chronic use of sibutramine is not related to anxiolytic effects (Figures $3 \mathrm{~A}$ and $3 \mathrm{~B}$ ), or even to its action in increasing locomotor activity through serotoninergic mechanisms (18). 
Furthermore, in contrast to what has been reported by Jorge and cols. (38), the acute treatment is not associated with anxiolytic effects (Figures $2 \mathrm{~A}$ and $2 \mathrm{~B}$ ). Jorge and cols. (38) described anxiolytic effects of sibutramine after a single administration.

We believe that the effect of inhibiting serotonin-noradrenaline reuptake by sibutramine which increases locomotor behavior $(9,18)$ and energy expenditure (9) with anti-obesity activity, makes it possible for this drug to be included in a class of SNRIs which are not effective in the treatment of anxiety. In addition, we believe that the mechanism of activity of antidepressant drugs and their influence not only on anxiety and depression may be important in the characterization and differentiation of these agents.

Acknowledgment: this research was sponsored and supported by Universidade Luterana do Brasil (Ulbra) through a scholarship for a young researcher scientific initiation program.

Disclosure: no potential conflict of interest relevant to this article was reported.

\section{REFERENCES}

1. Hainer V, Kabrnova K, Aldhoon B, Kunesova M, Wagenknecht M. Serotonin and norepinephrine reuptake inhibition and eating behavior. Ann NY Acad Sci. 2006;1083:252-69.

2. Bray GA, Ryan DH, Gordon D, Heidingsfelder S, Cerise F, Wilson K. A double blind randomized placebo-controlled trial of sibutramine. Obes Res. 1996;4(3):263-70.

3. Mcneely W, Goa KL. Sibutramine. A review of its contribution to the management of obesity. Drugs. 1998;56(6):1093-124.

4. Nisoli E, Carruba MO. A benefit-risk assessment of sibutramine in the management of obesity. Drug Saf. 2003;26(14):1027-48.

5. Gundlah C, Martin KF, Heal DJ, Auerbach SB. In vivo criteria to differentiate monoamine reuptake inhibitors from releasing agents: sibutramine is a reuptake inhibitor. J Pharmacol ExpTher. 1997;283(2):581-91.

6. Jackson HC, Needham AM, Hutchins LJ, Mazurkiewicz SE, Heal DJ. Comparison of the effects of sibutramine and other monoamine reuptake inhibitors on food intake in the rat. $\mathrm{Br} \mathrm{J}$ Pharmacol. 1997;121(8):1758-62.

7. Liu Y-L, Heal DJ, Stock MJ. Mechanism of the thermogenic effect of metabolite 2 (BTS 54505), a major pharmacologically active metabolite of the novel anti-obesity drug, sibutramine. Int $\mathrm{J}$ Obes. 2002;26(9):1245-53.

8. Strack AM, Shu J, Camacho R, Gorski JN, Murphy B, Macintyre $\mathrm{DE}$, et al. Regulation of body weight and carcass composition by sibutramine in rats. Obes Res. 2002;10(3):173-81.

9. Golozoubova V, Strauss F, Malmlöf K. Locomotion is the major determinant of sibutramine-induced increase in energy expenditure. Pharmacol Biochem Behav. 2006;83(4):517-27.

10. Buckett WR, Thomas PC, Luscombe GP. The pharmacology of sibutramine hydrochloride (BTS 54 524), a new anti-depressant which induces rapid noradrenergic down-regulation. Prog Neuropsychopharmacol Biol Psychiatry.1988;12(5):575-84.

11. Kelly F, Jones SP, Lee LK. Sibutramine weight loss in depressed patients. Int J Obes. 1995;19:145.
12. Luque CA, Rey JA. The discovery and status of sibutramine as an antiobesity drug. Eur J Pharmacol. 2002;440(2-3):119-28.

13. Thompson C. Mirtazapine versus selective serotonin reuptake inhibitors. J Clin Psychiatry. 1999;60(17):18-22.

14. Dazzi L, Vignone V, Seu E, Ladu S, Vacca G, Biggio G. Inhibition by venlafaxine of the increase in norepinephrine output in rat prefrontal cortex elicited by acute stress or by the anxiogenic drug FG 7142. J Psychopharmacol. 2002;16(2):125-31.

15. Vaishnavi SN, Nemeroff CB, Plott SJ, Rao SG, Kranzler J, Owens MJ. Milnacipran: a comparative analysis of human monoamine uptake and transporter binding affinity. Biol Psychiatry. 2004;55(3):320-22.

16. Brocco M, Dekeyne A, Veiga S, Girardon S, Millan MJ. Induction of hyperlocomotion in mice exposed to a novel environment by inhibition of serotonin reuptake. A pharmacological characterization of diverse classes of antidepressant agents. Pharmacol Biochem Behav. 2002;71(4):667-80.

17. Prinssen EPM, BallardTM, KolbY, Nicolas LB. The effects of serotonin reuptake inhibitors on locomotor activity in gerbils. Pharmacol Biochem Behav. 2006;85(1):44-9.

18. Frassetto SS, Rubio AD, Lopes JJ, Pereira P, Brum C, Khazzaka M, et al. Locomotor and peripheral effects of sibutramine modulated by 5-HT2 receptors. Can J Physiol Pharmacol. 2006;84(12):1239-44.

19. Melo CTV, Monteiro AP, Leite CP, Araújo FLO, Lima VTM, Barbosafilho JM, et al. Anxiolytic-like effects of (O-Methyl)- N-2,6-dihydroxybenzoyl-tyramine (Riparin III) from Aniba riparia (NEES) MEZ (Lauraceae) in Mice. Bio Pharm Bull. 2006;29(3):451-4.

20. Heal DJ, Cheetham SC, Prow MR, Martin KF, Buckett WR. A comparison of the effects on central 5-HT function of sibutramine hydrochloride and other weight-modifying agents. Br J Pharmacol. 1998b;125(2):301-8.

21. Giordano A, Centemeri C, Zingaretti MC, Cinti S. Sibutraminedependent brown fat activation in rats: an immunohistochemical study. Int J Obes Relat Metab Disord. 2002;26(3):354-60.

22. Heal DJ, Aspley S, Prow MR, Jackson HC, Martin KF, Cheetham SC. Sibutramine: a novel anti-obesity drug. A review of the pharmacological evidence to differentiate it from d-amphetamine and $d$ fenfluramine. Int J Obes Relat Metab Disord. 1998a; 22(1):S18-28.

23. Grignaschi G, Fanelli E, Scagnol I, Samanin R. Studies on the role of serotonin receptor subtypes in the effect of sibutramine in various feeding paradigms in rats. Br J Pharmacol. 1999;127(5):1190-4.

24. Pellow S, Chopin P, File SE, Briley M. Validation of open: closed arms entries in an elevated plus-maze as a measure of anxiety in the rat. J Neurosci Methods. 1985;14(3):149-67.

25. Rodgers RJ, Cole JC. The elevated plus-maze: pharmacology, methodology and ethology. In: Cooper SJ, Hendrie CA, editors. Ethology and psychopharmacology, Chichester: Wiley; 1994. p.9-43.

26. Moojen VKM, Martins MR, Reinke A, Feier G, Agostinho FR, Cechin EM, et al. Effects of milnacipran in animal models of anxiety and memory. Neurochem Res. 2006;31(4):571-7.

27. Drapier D, Bentué-Ferrer D, Laviolle B, Millet B, Allain H, Bourin M, et al. Effects of acute fluoxetine, paroxetine and desipramine on rats tested on the elevated plus-maze. Behav Brain Res. 2007;176(2):202-9.

28. Argyropoulos SV, Sandford JJ, Nutt DJ. The psychobiology of anxiolytic drugs. Part 2: pharmacological treatments of anxiety. PharmacolTher. 2000;88(3):213-27.

29. Miyamoto J,Tsuji M, Takeda H, Ohzeki M, Nawa H, MatsumiyaT. Characterization of the anxiolytic-like effects of fluvoxamine, milnacipran and risperidone in mice using the conditioned fear stress paradigm. Eur J Pharmacol. 2004;504(1-2):97-103.

30. Mochizuki D, Tsujita R, Yamada S, Kawasaki K, Otsuka Y, Hashimoto S, et al. Neurochemical and behavioural characterization of milnacipran, a serotonin and noradrenaline reuptake inhibitor in rats. Psychopharmacology (Berl). 2002;162(3):323-32. 
31. Chopin P, Briley M. Animal models of anxiety: the effects of compounds that modify $5-\mathrm{HT}$ neurotransmission. Trends Pharmacol Sci. 1987;8:383-9.

32. Lucki I. Serotonin receptor specificity in anxiety disorders. J Clin Psychiatry. 1996;57(6):5-10.

33. Griebel G. 5-Hydroxytryptamine-interacting drugs in animal models of anxiety disorders: more than 30 years of research. PharmacolTher. 1995;65(3):319-95.

34. Handley SL. 5-Hydroxytryptamine pathways in anxiety and its treatment. PharmacolTher. 1995;66(1):103-48.
35. Gordon JA, Hen R. The serotonergic system and anxiety. Neuromol Med. 2004;5(1):27-40.

36. Ninan PT. The functional anatomy, neurochemistry, and pharmacology of anxiety. J Clin Psychiatry. 1999;60(22):12-7.

37. Stahl SM, Grady MM, Moret C, Briley M. SNRIs: their pharmacology, clinical efficacy, and tolerability in comparison with other classes of antidepressants. CNS Spectr. 2005;10(9):732-47.

38. Jorge SD, Pobbe RLH, Soares VP, Oliveira AM, Zangrossi H. Effects of sibutramine on anxiety-related behaviours in rats. Pharmacol Res. 2004;50(5):517-22. 